\title{
Behavioral alterations due to coronavirus disease 2019
}

\section{Alteraciones conductuales por la enfermedad por coronavirus 2019}

Liliana R. Carlos-Gutiérrez* and Rogher H. Trejo-Rodríguez

Professional School of Human Medicine, Universidad Privada San Juan Bautista, Filial Chorrillos, Lima, Peru

Dear Editor,

With great interest we have read the research by Galindo et al., in which a study was carried out through an online survey in the general population with the purpose to determine behavioral alterations due to coronavirus disease 2019 (COVID-19). For this reason, we consider relevant to propose three therapeutic support measures in different populations:

- CONVIDA Line: it is a mobile psychological help line that allowed a marked reduction, of $60 \%$, of symptoms of anxiety and depression in the $\mathrm{Cu}$ ban population; therefore, implementing it in Peru could be highly useful. ${ }^{1}$

- Cognitive-behavioral techniques: based mainly on "thought stopping" for avoiding negative ideas that only cause considerable damage at the emotional level. $^{2}$
- Social networks: pages of updated information via social networks on preventive measures specifically addressing problems of anxiety and depression, in order to help coping with COVID-2019 in a more realistic form. ${ }^{2}$

In conclusion, psychological counseling by duly trained professionals is vital for being able to help with the treatment of the emotional imbalance caused by COVID-19 in different populations.

\section{References}

1. Valladares González AM, López Angulo LM. Línea CONVIDA. Propuesta de guía práctica psicológica ante la situación emergente de la COVID 19. Cienfuegos, 2020. MediSur. 2020;18(3):416-30.

2. Huarcaya-Victoria J. Consideraciones sobre la salud mental en la pandemia de COVID-19. Rev Peru Med Exp Salud Publica. 2020;37(2):327-34 license (http://creativecommons.org/licenses/by-nc-nd/4.0/).

Gac Med Mex. 2021:157:556

Contents available at PubMed www.gacetamedicademexico.com 